\title{
A DESCRIPTIVE ANALYSIS OF IT OUTSOURCING CONFIGURATION
}

\section{REYES GONZALEZ*}

Department of Business Organisation. University of Alicante. Carretera San VicenteAlicante. Zip Code: 03080. Alicante. SPAIN. Telephone and Fax No.: 34965903606. E-mail address: mr.gonzalez@ua.es

*Corresponding author

\section{JOSE GASCO}

Department of Business Organisation. University of Alicante. Carretera San VicenteAlicante. Zip Code: 03080. Alicante. SPAIN. Telephone and Fax No.: 34965903606. E-mail address: jl.gasco@ua.es.

\section{JUAN LLOPIS}

Department of Business Organisation. University of Alicante. Carretera San VicenteAlicante. Zip Code: 03080. Alicante. SPAIN. Telephone and Fax No.: 34965903606. E-mail address: juan.llopis@ua.es

\begin{abstract}
Information Systems outsourcing is a growing phenomenon in present-day firms that has generally been characterised with an insufficient level of detail and analysis. This is mainly due to the fact that outsourcing has been studied as a set of homogeneous services, failing to distinguish that there is a variety of contracts and ways to implement the outsourcing relationship. That is why this paper seeks to focus on a large number of essential aspects which define outsourcing contracts and relationships through the results of a survey carried out among the largest Spanish firms, suggesting the foreseeable future with respect to outsourcing in those companies.
\end{abstract}

\section{KEYWORDS}

Information Systems, Information Technology, Outsourcing, Survey, Descriptive Analysis, Spain.

Bibliographical notes: Reyes Gonzalez is a Senior Lecturer in Business Management and Information Systems at the University of Alicante. Her current research interests are Information Systems Management, E-Business and Outsourcing Processes. She has published articles in several journals, e.g. Information \& Management, Information Technology and People, Logistics Information Management, Total Quality Management, The International Journal of Educational Management, International Journal of Information Management, Information Management \& Computer Security, 
International Journal of Disclosure and Governance and Industrial Management \& Data Systems.

Jose Gasco is a Senior Lecturer in Business Management and Human Resources at the University of Alicante. His current research interests include Human Resources and Information Systems Outsourcing. He has published articles in several journals, namely, Revue Internationale P.M.E., Direction et Gestion des Entreprises, Corporate Communications: An International Journal, The International Journal of Public Sector Management, Business Process Management Journal, Total Quality Management, Information Technology and People, Logistics Information Management, International Journal of Information Management, Information Management \& Computer Security, International Journal of Disclosure and Governance and Industrial Management \& Data Systems.

Juan Llopis is Full Professor and Dean of the Faculty of Economics and Business at the University of Alicante. His current research lines include Organisational Culture, Human Resources, Quality Management and Information Systems Management. He has published articles in journals such as Information \& Management, Total Quality Management, Journal of High Technology Management Research, Corporate Communications: An International Journal, Information Technology and People, Logistics Information Management Journal, International Journal of Value-Based Management, International Journal of Information Management, Information Management \& Computer Security, International Journal of Disclosure and Governance and Industrial Management \& Data Systems.

\section{INTRODUCTION}

Information Systems (IS) outsourcing has become a basic strategy as far as the management of the unstoppable changes triggered by Information Technologies (IT) ${ }^{1}$ is concerned (Akomode, Lees, and Irgens, 1998; Hoecht and Trott, 2006). This gives IS managers the opportunity to concentrate their resources on core competitive powers (Leem and Lee, 2004). For this reason, among others, IS outsourcing has experienced a considerable growth in the last few years, as is shown by the fact that this market moved over 185 billion $€$ all over the world in 2005 (IDATE Foundation, 2005). Forrester estimates that the worldwide IT and applications outsourcing market is now worth about $\$ 120$ billion per year (Takahashi and Sayer, 2007) and forecasts that European firms

\footnotetext{
${ }^{1}$ No distinction is made between Information Services (IS) and Information Technologies (IT) in this paper. Both expressions have been used interchangeably as synonyms with the only aim of increasing the reader-friendliness of the exposition.
} 
will increase their IT outsourcing expenditure even more in 2008 (Forrester, 2004). In turn, the Gartner group expects the worldwide IT outsourcing market to grow from the $\$ 180.5$ billion revenues registered in 2003 to the $\$ 253.1$ billion foreseen for 2008 , whereas computer market analysts such as KPMG argue that IT outsourcing is still growing and that firms following this practice will surely want to maintain or increase their outsourcing level (KPMG, 2007).

Many studies on IS outsourcing have reached contradictory conclusions, providing reasons both for the growth (Alner, 2001; Ang and Straub, 1998; Gonzalez, Gasco and Llopis, 2005; McLellan, Marcolin and Beamish, 1995) and for the decline of this trend based, in the latter case, on the various risks associated with the application of IT outsourcing practices (Barthélemy, 2001; Earl, 1996; Palvia, 1995; Tafti, 2005; Willcocks, Lacity and Kern, 1999). Evaluating IT outsourcing decisions is highly problematic at the moment (Chen, Chou and Lin, 2007), mainly because outsourcing has often been viewed as a set of homogeneous services, failing to recognise the existence of various outsourcing contracts and relationships. In fact, the highest level of detail achieved in previous studies was the specification of the IS activities outsourced. For this reason, the purpose of the present paper is basically to offer a more detailed description of IT outsourcing contracts and relationships using the results from a survey carried out among the largest Spanish firms. An in-depth study focusing not only on the most often outsourced activities but also on other attributes which capture the essence of the different outsourcing contracts -i.e. what Cullen, Seddon and Willcocks (2005) call 'the IT outsourcing configuration' - has been performed. To carry out this study our purpose is to answer 7 relevant questions about the IT outsourcing configuration, which will be described in the next section. A longitudinal analysis for many of these attributes is proposed that will help to foresee the future of IT outsourcing. 


\section{METHODOLOGY}

Based on the assumption that the largest firms are also the most prone to outsourcing (Lee, Miranda and Kim, 2004), a decision was made to administer the questionnaire to the largest Spanish firms. The directory "Las 5.000 mayores empresas" (The 5,000 largest firms) of the Actualidad Económica magazine - later collated with other databases largely used in business studies such as Duns and Bradstreet's “50,000 Principales Empresas Españolas" (the main 50,000 Spanish firms) - served to specify the target population. An effort was made to find out which of the 5,000 firms with the highest sales included in the first database list mentioned above had the same telephone numbers and addresses, as this was a clear symptom of coincidence between the IS manager and the structure itself. With that information at hand, it was decided that the questionnaire would only be sent to the firm which, having the same telephone number and address as others, showed the highest sales.

893 firms were eliminated in this way, leaving a final database of 4,107 firms that received a questionnaire along with a stamped addressed envelope for the questionnaire to be returned. The questionnaire, which largely stems from a previous one prepared by the same authors in 2001 and based, the same as this one, on the literature devoted to this issue, has additionally been analysed by a number of experts on IS management ${ }^{2}$. Only 13 out of the 26 questions in the final questionnaire were used here, because this paper forms part of a larger empirical study dealing with a wide range of aspects related to IS outsourcing. 4 of those 13 questions define the general profile of the firms analysed, their IS departments and their managers (CIO - Chief Information Officer); 8

\footnotetext{
${ }^{2}$ Special mention must be made here of the collaboration provided by Mr. Juan Manuel Aparicio and Mr. Ramón Andarias.
} 
refer to the characteristics of outsourcing contracts and relationships; and 1 requests the interviewees' opinion about the future of outsourcing. The 8 questions about outsourcing contracts and relationships ('the IT Outsourcing Configuration') derived mainly from the study of Cullen, Seddon and Willcocks $(2005)^{3}$, according to which an outsourcing relationship is defined by the following attributes:

1. Outsourcing scope, which describes what services are outsourced (e.g. development, programming, maintenance), who receives those services (a department, division or corporate level) and whether outsourcing is implemented nationally or globally.

2. Number of providers, since outsourcing can relate one client to one or several providers.

3. Financial scale, which refers to the financial dimension of outsourcing or to the outsourcing level, i.e. to whether it is total or selective outsourcing. When it comes to analysing the results, this issue will be presented together with the results corresponding to the first attribute (outsourcing scope).

4. Price structure, as there can be one price fixed by contract, one that depends on the contract (on its length, for instance) and another one based on the cost that the services mean to the provider.

5. Contract length (duration).

6. Resource ownership; in this respect, one should specify who owns the hardware and the software and even where the outsourced services are delivered (at the client's or at the provider's facilities).

7. Client-provider commercial relationship, which can range from the case in which the organisations are totally independent of one another to that in which the provider is a subsidiary or affiliate of the client firm.

\footnotetext{
${ }^{3}$ Cronbach's Alpha for the group of variables which define the IT Outsourcing Configuration is 0.832 , which indicates the reliability of the scale.
} 
The questionnaire's addressee was the IS manager or CIO of the firms included in the final database. A new inconvenience arose here, because unlike what happens in other countries, no listings of these managers were available in Spain. In other words, the addressee's identity was not known. The information obtained in the questionnaire had to be elaborated upon later using the statistical program SPSS for Windows and applying univariant and multivariant statistical methods. Table 1 shows the study specifications.

\section{INSERT TABLE 1}

329 valid answers were obtained, which represents an $8 \%$ ratio. This ratio might seem low, but similar or even lower ratios can be found in other studies about IT Outsourcing (Bahli and Rivard, 2005; Gonzalez, Gasco and Llopis, 2005; Ma, Pearson and Tadisina, 2005; Shi, Kunnathur and Ragu-Nathan, 2005). In fact, the ratio is quite acceptable bearing in mind the problems to obtain answers in surveys carried out among executives, especially when they are IS executives. This has to do with the fact that the rapid technological change, the considerable IT-related investments carried out by firms and the great interest aroused by outsourcing have made these executives become the target of many surveys (Poppo and Zenger, 1998). Since part of this study focuses on analysing the evolution over time of the answers provided by our interviewees, Table 2 shows the basic characteristics not only of this survey but also of the previous one, which served as a reference to see that evolution. It is impossible to ascertain whether the firms which answered this questionnaire and those which answered the preceding one are the same. Previous longitudinal studies (e.g. Casadesús and Karapetrovic, 2005) were addressed to the same population, but this does not necessarily mean that both samples coincide. The firms which answered the questionnaire correctly are 
representative of the total population in terms of size (sales and number of employees) and sector ${ }^{4}$.

\section{RESULTS}

\subsection{General characteristics of the firms}

\section{INSERT TABLE 2}

Table 2 shows the general features of the interviewed firms, their IS departments and their IS managers, both in the present study and in the one carried out in 2001. Regarding firm size, which may be measured by sales and number of employees, the organisations interviewed for this study have a considerable size in relation to both variables, as the lowest percentages correspond to the firms with the fewest employees (only $8.5 \%$ of them have less than 50 workers) and sales $(9.4 \%$ of the firms have an annual turnover below 30 million, while $44.3 \%$ of them turn over between 30 and 60 million a year and another $35 \%$, between 60 and 300 million).

Most of the firms under examination belong to the industrial sector (57.4\%). A differentiation has been made within the service sector between general services and ITintensive ones (financial institutions and insurance companies, as well as those belonging to the tourism, law and publishing sectors) because these organisations depend much more than the rest on their IT, due to the type of product/service they offer and its elaboration process (Capaldo, Raffa and Zollo, 1995). 11.6\% of the responses came from this sector.

Despite the size of firms, their IS departments are rather low-staffed: the vast majority of them $(76 \%)$ have 10 or fewer employees in this department. Neither do they allocate

\footnotetext{
4 A T-test was used to verify the possible differences regarding the number-of-employees mean both for firms which answered the survey and for those which did not, with T having a value of -1.080 with a 0.280 significance level. In the case of sales, a non parametric test -Mann-Whitney's U-test- with a value of 444732.5 and a 0.338 significance level was used. A Chi-square test served to see the connection between the industrial sector and the response or lack of response by firms. The Chi value was 2.802 and the significance level, 0.246 . These results imply the existence of a non-response bias in relation to these three variables. All the statistics were calculated with a 0.05 significance level.
} 
a large proportion of the budget to it, as a large part of the organisations $(41.9 \%)$ dedicate $4 \%$ or less of their overall budget to IS. It can thus be said that although these firms have a considerable size, they allocate few financial and human resources to their IS departments. As it happened in 2001, many interviewees did not give a precise answer about the percentage of the budget dedicated to IS, which is, incidentally, quite common in other studies devoted to the same issue (Lee, 2001).

Among the significant features of IS managers — the interviewees - identified stands out that they have had this job for about 8 years on average and are more or less 42 years old. This responsibility position continues to be mostly held by males. Regarding the hierarchical level within the organisation, more than half of the interviewees report directly to the General Manager (59\%), which is the most convenient option because it avoids dependency on a specific functional area and allows a broader, more objective vision of the firm as a whole. However, a smaller though still significant percentage of interviewees depend on Finance and Administration (24.9\%).

\subsection{The IT Outsourcing Configuration}

\section{Outsourcing Scope}

\section{INSERT TABLE 3}

As can be seen in Table 3, outsourcing has become a widespread phenomenon in the largest Spanish firms: $83.6 \%$ of them outsource some of their IS functions nationally. However, a comparison with previous years reveals a certain degree of stagnation, i.e. outsourcing levels have not increased during the last few years. Additionally, Spanish firms still show a 'shy' approach to global or international outsourcing — where the service provider and the client are not in the same country (IDC, 2005; Gonzalez, Gasco and Llopis, 2006; Kumar, 2006). Because global outsourcing levels are so low and insignificant, this paper does not even analyse which activities have been outsourced on 
a global scale, as even the most commonly outsourced activities show negligible percentages (for instance, software maintenance has an average outsourcing level of $5.38 \%$ and client telephone attention and data introduction, which are very often outsourced internationally, only reach the extremely low figures of $2.58 \%$ and $1.28 \%$ in Spain).

Figure 1 offers the percentage mean for each outsourced IS activity. Attention is focused on activities specific to one IS department and on the extent to which those activities are outsourced by the interviewed firms. Hardware and software maintenance, systems installation and programming are the activities in which the help of an external provider is most often requested. The opposite case corresponds to staff service and training, e-business solutions, support to end users and systems operation, which are rarely outsourced.

\section{INSERT FIGURE 1}

In any case, except for hardware maintenance, the firms under examination do not outsource a sizeable proportion of their IS activities. Instead, they carry out what has come to be known as "selective outsourcing" (Lacity, Willcocks and Feeny, 1996). Furthermore, it is easier to justify which activities are the most often outsourced. They are the least specific ones, as well as those requiring the least special attention to the characteristics of clients. In other words, they tend to be highly standardised activities. On the one hand, it is common for hardware and software maintenance to be carried out by external providers as an additional updating service. On the other hand, the most routine part of systems development - i.e. programming or systems installation - is often outsourced during work peaks in this area.

Figure 1 provides a longitudinal comparison between the 2006 data and those corresponding to 2001. On the whole, a similar outsourcing pattern can be identified in 
both dates. In fact, the outsourcing-related variables for the different activities in 2006 and 2001 are dependent in nearly all cases, especially for the most-often-outsourced activities $^{5}$. It is also worthy of mention that, although hardware maintenance continues to be the most commonly outsourced activity, its outsourcing level has diminished in recent years. The same applies to programming. Nevertheless, other activities such as network services have largely increased their outsourcing levels. The importance acquired by the connections to the Internet as well as to other public and private networks has made this value grow. The security service increases in parallel with the preceding variable, as connection to networks reinforces the need to strengthen systems security. A special mention must be made of e-business solutions outsourcing, insofar as the increasing importance of electronic businesses might actually be the reason for the growth of outsourcing levels. It is also important to highlight that training —one of the most often outsourced activities in 2001, when it ranked fifth on the outsourcing list - is the least outsourced activity according to the 2006 survey. This may suggest either a lesser need for training due to the increased knowledge on the part of end users or a greater IS department capability to carry out these tasks internally.

\section{INSERT FIGURE 2}

As shown in Figure 2, when the largest Spanish firms outsource, they usually (in 56\% of the cases) do so on an organisation-wide scale. The number of cases in which outsourcing takes place differentiating the various divisions existing within a firm is smaller and it is still much less common to outsource functions which only affect one department - this happens in only $7 \%$ of the cases.

\footnotetext{
${ }^{5}$ A difference-of-means test was performed using Student's T and Mann-Whitney's U tests for those variables which are not parametric. The results show the dependency of values for variables related to programming, hardware and software maintenance, network service and support to end users both in 2006 and in 2001. Instead, the variables corresponding to the least-often-outsourced activities, namely security, training, systems operation and analysis do not show any dependency in either. The only exception is the value for installation, an activity which stands out as one of the most commonly outsourced ones but appears as an independent variable in the responses obtained in both surveys.
} 


\section{Number of providers}

In keeping with the advice of the literature on this aspect, firms still tend to work with more than one provider when it comes to outsourcing their IS activities (see Figure 3). The multiple-provider option allows the client firm to negotiate outsourcing contracts with a variety of providers differentiated by competence, experience and market positioning (Cross, 1995), which makes the different providers' skills complementary. However, this option has its risks too, such as the difficulty to manage and coordinate the work of several providers (Currie and Willcocks, 1998) as well as to specify the responsibilities to be assumed by each one of them (Loh and Venkatraman, 1992), especially when the outsourced processes are interdependent. A comparison between 2001 and 2006 reveals that more than one provider was used for the same activities in 2001. It can therefore be said that the strategy has been maintained until the present day.

\section{INSERT FIGURE 3}

Nevertheless, Figure 4 shows that, although the tendency to have a number of different providers still prevails, it is no longer as strong as it used to be. Except for IT security and systems operation, the inclination to look for several providers was stronger in 2001 than in 2006 for all activities. This probably results from the strengthened relationships deriving from contract maturity, which reflects a degree of confidence in certain providers that can eventually lead to the creation of a partnership or a true alliance with them.

\section{INSERT FIGURE 4}

\section{Price structure}

Figure 5 illustrates which Spanish firms prefer to have a fixed price as a way to guarantee what outsourcing is going to bring them. This price-fixing method is appropriate when the outsourcing client's level of demand can be predicted (Cullen, 
Seddon and Willcocks, 2005). Contracts are much less frequently based on the service units received (for example, the number of payrolls processed by the provider). This second method implies that clients pay only for what they consume. A third method exists in which contract price depends on the costs that providers must incur in order to supply services to their clients. This option can generate a certain degree of opportunism on the part of the provider (Lacity and Willcocks, 1995), who can decide to inflate costs disproportionately. No wonder this is the least commonly used way to finance outsourcing.

\section{INSERT FIGURE 5}

\section{Length}

Most contracts last less than one year, with a smaller group of them being made for a period of 1-to-5 years and, finally, another group where length is not defined because it depends on the project (see Figure 6). Longer contracts —with lengths of 5-or-10 years and more than 10 years - are less frequent though. In fact, none of the firms in the 2006 survey claims to have contracts lasting over 10 years, which means that the firms interviewed follow the postulates of the literature, according to which the signature of short-term contracts seems to be the best option to minimise the risks associated with outsourcing (Currie, 1998, Earl, 1996; Hurst and Hanessian, 1995, Lacity, Willcocks and Feeny, 1995). This gives more flexibility to clients, who can credibly maintain the threat that they will look for another provider if they are not satisfied with the provider's performance at the end of the contract, something that would prove much more difficult to do in a long-term contract. Previous surveys have equally confirmed the tendency to prioritise short-term contracts (Cullen, Willcocks and Seddon, 2001), though the debate about the convenience of short- or long-term contracts is still alive. For instance, Kepler and Jones (1998) argue that long-term contracts make it possible to establish a mutual 
agreement between the parties as well as a shared-learning process, and Lee, Miranda and Kim (2004) point out that in some cultures, such as the Korean one, long-term contracts are a reflection of the value that the culture in question assigns to stable relationships.

\section{INSERT FIGURE 6}

Regarding contract length, similar behaviour patterns are identified in both the 2006 and the 2001 surveys $^{6}$. The only outstanding difference which could possibly deserve to be mentioned refers to the preference for contracts of either 1-to-5 years or 5-to-10 years in 2006, whereas shorter-term contracts (of up to one year) and those in which the length depends on the contract (both of them the most flexible ones for the client) were more frequent in 2001. This can once again be interpreted as a reflection of the greater maturity or expertise of many firms in outsourcing contracts, which makes them more likely to sign longer-term contracts based on their wider knowledge and their confidence with respect to the provider.

\section{Resource ownership}

\section{INSERT TABLE 4}

The complexity of the outsourcing decision not only affects the functions being outsourced but also the definition of the ownership status for the resources incorporated into the outsourced IS functions (Dibbern, Goles, Hirscheeim and Jayatilaka; 2004). Table 4 demonstrates that the client owns both the hardware and the software in the outsourcing contracts signed by the largest Spanish firms (the mean and the mode are 7 with respect to both aspects). Additionally, the outsourced services can be delivered onsite (at the client's facilities) or off-site (at the provider's facilities), a preference being

\footnotetext{
${ }^{6}$ Some tests - namely, a Student's T-test for the difference of means and a non-parametric MannWhitney's U-Test- have been performed in order to identify the degree of statistical dependency in interviewees' answers for this question in 2001 and 2006, and except for the case of contracts of up to one year, the rest of answers show statistical dependency for responses in both studies.
} 
identified for service delivery at the client's facilities among Spanish firms. This means that the provider's employees go to the client firm's premises, which very often leads to the creation of work and trust links between the staff of both organisations and benefits the outsourcing relationship (Zufiria, 2006).

\section{Commercial relationship}

A final characteristic of the outsourcing contract would refer to the determination of the commercial relationship existing between the client and the provider firm. This link can range between total independence of the firms — with only a market-based contractual link - and a rather strong mutual dependency, which partly eliminates the risk of opportunism and ensures the quality conditions in the service received by the client —as in the case where the provider is an affiliate or subsidiary of the client firm. Nevertheless, some authors claim that this is really a "quasi-outsourcing" rather than a true outsourcing relationship (Barthélemy and Geyer, 2005).

\section{INSERT FIGURE 7}

The interviewees were asked to define the relationships with their providers. The answers showed that the link does not often go beyond the outsourcing contract (See Fig. 7). Although this is not so common, there are cases in which some initiatives are shared despite the absence of ownership relationships (Alvarez-Suescun, 2007), which represents a first step toward the maturity of outsourcing contracts, as joint initiatives can lead to a partnership-type link in which the services hired acquire more added value (Gottschalk and Solli-Sather, 2007). The cases in which either the client owns part of the social capital of the provider or the latter is an affiliate or a subsidiary of the client firm are less common.

\subsection{The future of outsourcing}

INSERT FIGURE 8 
Figure 8 reflects the interviewees' opinion about the future of outsourcing in the largest Spanish firms. The answers are conservative, since most of the interviewees indicate that they will maintain the internal-external service ratio. It stands out that outsourcing grows on a national scale at the expense of firms' IS internal services, which are expected to be either reduced or, less often, removed altogether. The answers related to the future of international outsourcing are not very significant, which clearly indicates that this type of outsourcing is far from being consolidated in Spain. Finally, the reduction or elimination of outsourcing, either nationally or globally, seems much more unlikely.

\section{INSERT FIGURE 9}

The longitudinal study (Figure 9) shows that the proneness to reduce or remove internal services in order to adopt outsourcing is greater in 2006 than in 2001. However, international outsourcing still finds itself at a very early stage of development in Spain, its prospects for the future not being too bright either, at least in the short term.

\section{CONCLUSIONS}

It can be said that the present paper has succeeded in achieving its objectives, as responses have been found for the 8 basic questions posed about 'the IT outsourcing configuration' in the Spanish case, thanks to which a very detailed description of IT outsourcing relationships and contracts in Spain has been made.

In short, IS outsourcing has become a widespread phenomenon, both internationally and in the specific context of the largest Spanish enterprises, though the IS outsourcing rate in these enterprises seems to have decreased in recent years, particularly in the field of global outsourcing, in which Spain has clearly been left behind. 
Selective outsourcing still seems to be preferred by Spanish firms, which outsource the most specific activities requiring a lesser degree of adaptation to each client's special features. The outsourcing of activities is mostly applied on an organisation-wide scale, and not at a specific division or department level.

Following the advice in the literature on this matter, the interviewed firms tend to choose more than one provider in their outsourcing contracts, thus avoiding dependency on a single provider and reducing the risk of potential opportunistic behaviours on the part of providers. However, this multiple-provider tendency has become less marked during the last few years, which can suggest a greater degree of confidence with certain providers that could even lead to the creation of partnerships or alliances with them.

Fixed prices and short length prevail in the IS outsourcing contracts signed in Spain, probably trying to avoid being tied to a single provider that might deliver a poor service. The number of longer-term contracts has increased in recent years, though. This once again indicates a higher degree of maturity or experience on the part of the client, who dares to establish closer links with providers based on higher experience and confidence levels.

Firms prefer outsourced activities to be carried out at their own facilities and with their own hardware and software. Although they do not usually have ownership links with their outsourcing providers, both organisations share joint initiatives in some cases, thus taking the first step toward a closer client-provider relationship.

As for the future of outsourcing in Spain, it definitely seems to be guaranteed, because the interviewed firms confirm a greater proneness to reduce or eliminate external services in favour of national outsourcing.

The present paper provides a longitudinal study on IS — which is somehow limited, though, insofar as it could only be carried out with several variables (the ones about 
which information was available in 2001). In addition to that, it was only possible to compare two moments in time (2001 vs. 2006), as a result of which the longitudinal has had an exclusively descriptive nature. Therefore, a potential enlargement of this research study could mean collecting more information in the future and using more sophisticated analyses, all of which will make it possible both to compare three different moments in time and to determine the extent to which trends are being consolidated.

IS outsourcing is a complex decision which not only refers to whether or not it is advisable to outsource and to the choice of specific activities that should be outsourced. Researchers as well as managers must be aware of the wide variety of decisions which surround IT outsourcing and contracts. In this respect, the contents offered in this paper should hopefully contribute to deepen in the level of detailed knowledge required for a thorough comprehension of IT outsourcing.

\section{REFERENCES}

Akomode, O.J.; Lees, B. and Irgens, C. (1998). "Constructing customised models and providing information to support IT outsourcing decisions". Logistics Information Management. Vol. 11, No. 2, pp. $114-127$.

Alner, M. (2001). "The Effects of Outsourcing on Information Security". Information Systems Security. Vol. 10, No. 2, pp. 35-43.

Alvarez-Suescun, E. (2007). "Testing Resource-Based Propositions about IS Sourcing Decisions". Industrial Management \& Data Systems. Vol. 107. No. 6. pp. $762-779$

Ang, S. and Straub, D. (1998). "Production and Transaction Economies and IS Outsourcing: A Study of the U.S. Bank Industry". MIS Quarterly, Vol. 22, No. 4, pp. 535-552.

Bahli, B. and Rivard, S. (2005). "Validating Measures of Information Technology Outsourcing Risk Factors". Omega. Vol. 33, No. 2, pp. 175-187.

Barthélemy, J. (2001). "The Hidden Cost of IT Outsourcing”. MIT Sloan Management Review. Vol 42, No. 3, pp. 60-69.

Barthélemy, J. and Geyer, D. (2005). "An empirical investigation of IT outsourcing versus quasi-outsourcing in France and Germany", Information \& Management, Vol. 42, No. 4, pp. 533-542.

Capaldo, G., Raffa, M. and Zollo, G. (1995). "Factors influencing successful implementation of computer-based technologies in knowledge-intensive activities" .Information Resources Management Journal. Vol. 8, No. 4, pp. 29-37.

Casadesús, M. and Karapetrovic, S. (2005). "Has ISO 9000 lost some of its lustre? A longitudinal impact study?" International Journal of Operations and Production Management. Vol. 25, No. 6, pp. 580-596.

Chen, J-R.; Chou, T-C. and Lin, Y-C. (2007). "Design and Implementation of an Ontology-based Information Technology Outsourcing Evaluation Systems using AHP". International Journal of Innovation and Learning. Vol. 4. No. 1. pp. 74-91. 
Cross, J. (1995). “IT Outsourcing: British Petroleum's Competitive Approach". Harvard Business Review. May-June, pp. 94-102.

Cullen, S.; Willcocks, L.P. and Seddon, P.B. (2001). "Information Technology Outsourcing Practices in Australia". Deloitte Touche Tohmatsu. Sydney.

Cullen, S.; Seddon, P.B. and Willcocks, L.P. (2005). "IT outsourcing Configuration: Research into Defining and Designing Outsourcing Arrangements". Journal of Strategic Information Systems. Vol. 14, No. 4, pp. 357-387.

Currie, W.L. (1998). "Using Multiple Suppliers to Mitigate the Risk of IT Outsourcing at ICI and Wessex Water". Journal of Information Technology. Vol. 13, No. 3, pp. 169-180.

Currie, W.L. and Willcocks, L.P. (1998). "Analysing Four Types of IT Sourcing Decisions in the Context of Scale, Client/Supplier Interdependency and Risk Mitigation". Information Systems Journal. Vol 8, No. 2, pp. 119-143.

Dibbern, J.; Goles, T.; Hirschheim, R. and Jayatilaka, B. (2004). "Information Systems Outsourcing: A survey and Analysis of the Literature". Database for Advances in Information Systems. Vol. 35, No. 4, pp. 6-102.

Earl, M.J. (1996). "The Risk of Outsourcing IT". Sloan Management Review. Vol. 37, No. 3, pp. 26-32.

Forrester (2004). "Europe's IT services spending will grow by 57 percent from 2003 to 2008 ". Internet Document. http://www.t-systems.com/ipl2/statistics/923/downloads/press_kits/).

Gonzalez, R.; Gasco, J. and Llopis, J. (2005). "Information Systems Outsourcing Reasons in the Largest Spanish Firms". International Journal of Information Management. Vol. 25, No. 2, pp. 117-136.

Gonzalez, R. Gasco, J. and Llopis, J. (2006). "Information Systems Offshore Outsourcing: A Descriptive Analysis". Industrial Management \& Data Systems. Vol. 106, No. 9, pp. 12331248.

Gottschalk, P. and Solli-Sather, H. (2007). "Knowledge Transfer in IT Outsourcing Relationships: Three International Case Studies". International Journal of Innovation and Learning. Vol. 4, No. 2. pp. 103-111.

Hoecht, A. and Trott, P. (2006). "Innovation Risks of Strategic Outsourcing". Technovation. Vol. 26, No. 5-6, pp. 672-681.

Hurst, I. and Hanessian, B.G. (1995). "Navigating IT Channels: Integrate or Outsource?", The McKinsey Quarterly, Vol. 3, pp. 103-110.

IDATE Foundation (2005). "Digiworld 2005. Los retos del mundo digital" IDATE-ENTER, Montpellier, France. Internet document.

http://enter.es/enter/file/espanol/texto/digiworld.2005.pdf

IDC (2005) "Estudio sobre el atractivo de España como destino del Nearshore". Internet Document unloaded 16 September 2005.

http://www.idc.com/spain/downloads/research/fs_nearshore.pdf

Kepler, R. and Jones, W.O. (1998) "Outsourcing Information Technology Systems and Services". Prentice Hall, New Yersey.

KPMG (2007). "Strategic Evolution. A global Survey on Sourcing Today". Internet document, downloaded at 28 February 2007.

http://www.kpmg.com.au/Portals/0/rasita_strategic-evolution200701.pdf

Kumar, S. (2006). "A Comparative Analysis of Key Information Technology Players". Technovation. Vol. 26, No. 7, pp. 836-846.

Lacity, M.C. and Willcocks, L.P. (1995). "Interpreting Information Technology Sourcing Decisions from a Transaction Cost Perspective: Findings and Critique". Accounting, Management \& Information Technology, Vol. 5, No. 3/4, pp. 203-244.

Lacity, M.C.; Willcocks, L.P. and Feeny, D.F. (1995). "IT Outsourcing Maximize Flexibility and Control”. Harvard Business Review, May-June, pp. 84-93.

Lacity, M.C., Willcocks, L.P. and Feeny, D.F. (1996). "The value of selective sourcing". Sloan Management Review, Vol. 37, No. 3, pp. 13-25.

Lee, J-N. (2001). "The impact of knowledge sharing, organizational capability and partnership quality on IS outsourcing success". Information \& Management. Vol. 38, No. 5, pp. 323-335. 
Lee, J-N. Miranda, S.M. and Kim, Y-M. (2004). "IT Outsourcing Strategies: Universalistic, Contingency, and Configurational Explanations of Success". Information Systems Research. Vol. 15, No. 2, pp. 110-131.

Leem, Ch.S and Lee, H.J. (2004). "Development of Certification and Audit Processes of Application Service Provider for IT Outsourcing”. Technovation. Vol. 24, No. 1, pp. 63-71.

Loh, L. and Venkatraman, N. (1992). "Diffusion of Information Technology Outsourcing: Influence sources and the Kodak Effect". Information Systems Research. Vol. 3, No. 4, pp. 334358.

Ma, Q.; Pearson, J.M. and Tadisina, S. (2005) "An Exploratory Study into Factors of Service Quality for Application Service Providers". Information \& Management. Vol. 42, No. 4, pp. 1067-1080.

McLellan, K.; Marcolin, B. and Beamish, P. (1995). "Financial and Strategic Motivations behind IS Outsourcing". Journal of Information Technology, Vol. 10, No. 4, pp. 299-321.

Palvia, P.C. (1995). "A dialectic view of information systems outsourcing: Pros and cons". Information \& Management. Vol. 29, No. 5, pp. 265-275.

Poppo, L. and Zenger, T. (1998). "Testing alternative theories of the firm: transaction cost, knowledge-based, and measurement explanations for make-or-buy decisions in information services". Strategic Management Journal. Vol. 19, No. 9, pp. 853-877.

Shi, Z.; Kunnathur A.S. and Ragu-Nathan, T.S. (2005). "IS Outsourcing Management Competence Dimensions: Instrument Development and Relationship Exploration". Information \& Management. Vol. 42, No. 6, pp. 901-919.

Tafti, M.H.A. (2005). "Risk factors associated with offshore IT outsourcing", Industrial Management \& Data Systems, Vol. 105, No. 5, pp. 549-560.

Takahashi, S. and Sayer, P. (2007). "European IT/Telecom Converged Service Delivery Outsourcing Deals: H1 2006. The Battle Rages between IT and Telecom Service Providers". Internet document downloaded at 28 February 2007.

http://www.forrester.com/rb/search/results.jsp?No=25\&N=50174

Willcocks, L.P., Lacity, M.C. and Kern, T. (1999). "Risk Mitigation in IT Outsourcing Strategy Revisited: Longitudinal Case Research at LISA". Journal of Strategic Information Systems. Vol. 8, No. 3, pp. 285-314.

Zufiria J.A. (2006). 'Key Issues for a successful employee's transference process in outsourcing projects". Universia Business Review, No. 9, pp. 98-103. 
Table 1: Study Technical Specifications

\begin{tabular}{|l|l|l|}
\hline & Year 2001 & Year 2006 \\
\hline Scope & Spain & Spain \\
Population & 4,416 largest Spanish business (by sales) & 4,107 largest Spanish business (by sales) \\
Sample size & 357 valid answers (8.08\%) & 329 valid answers $(8.02 \%)$ \\
Sampling error & $5 \%$ & $5 \%$ \\
Survey date & June-October, 2001 & September-December, 2006 \\
\hline
\end{tabular}

Table 2: General Characteristics of the Firms

\begin{tabular}{|c|c|c|c|c|c|}
\hline & & 20 & & & \\
\hline & & $\mathrm{N}$ & $\%$ & $\mathrm{~N}$ & $\%$ \\
\hline & $0-50$ & 22 & 6.2 & 28 & 8.5 \\
\hline No. of & $51-500$ & 202 & 56.6 & 218 & 66.2 \\
\hline employees & More than 500 & 132 & 36.9 & 76 & 23.1 \\
\hline & Lost & 1 & 0.3 & 7 & 2.1 \\
\hline & Up to 30 & 36 & 10.1 & 31 & 9.4 \\
\hline & More than 30 up to 60 & 227 & 63.6 & 146 & 44.3 \\
\hline (million $f$ ) & More than 60 up to 300 & 38 & 10.6 & 115 & 35.0 \\
\hline & More than 300 & 55 & 15.4 & 30 & 9.2 \\
\hline & Lost & 1 & 0.3 & 7 & 2.1 \\
\hline & Industry & 210 & 58.8 & 189 & 57.4 \\
\hline Sector & Services & 118 & 33.1 & 102 & 31.0 \\
\hline & Intensive IT Services & 29 & 8.1 & 38 & 11.6 \\
\hline & 1-10 Workers & 240 & 67.2 & 250 & 76.0 \\
\hline & 11-100 Workers & 96 & 26.9 & 66 & 20.1 \\
\hline is stajJ & 101-250 Workers & 5 & 1.4 & 6 & 1.8 \\
\hline & Lost & 16 & 4.5 & 7 & 2.1 \\
\hline & $0-4$ & 133 & 37.2 & 138 & 41.9 \\
\hline Duaget & $5-10$ & 61 & 17.1 & 56 & 17.0 \\
\hline $\begin{array}{l}\text { perceniage } \\
\text { allocated to IS }\end{array}$ & $11-56$ & 18 & 5.1 & 13 & 4.0 \\
\hline allocatea to is & Lost & 145 & 40.6 & 122 & 37.1 \\
\hline & Male & 321 & 89.9 & 293 & 89.0 \\
\hline CIO Sex & Female & 25 & 7.0 & 27 & 8.2 \\
\hline & Lost & 11 & 3.1 & 9 & 2.7 \\
\hline & General Management & 193 & 54.1 & 194 & 59.0 \\
\hline Work post of the & Finance/Administration & 101 & 28.3 & 82 & 24.9 \\
\hline CIO's direct & Corporation IS manager & 17 & 4.8 & 30 & 9.1 \\
\hline superior & Organisation/planning/engineering & 20 & 5.6 & 4 & 1.2 \\
\hline & Lost & 26 & 7.3 & 19 & 5.8 \\
\hline & Mean & 7.4 & & 8.43 & \\
\hline CIO's length of & Median & 5.0 & & 6.0 & \\
\hline service & Minimum & 1.0 & & 0.5 & \\
\hline & Maximum & 30.0 & & 35.0 & \\
\hline & Mean & 41.0 & & 42.3 & \\
\hline CIO's age & Median & 40.0 & & 42.0 & \\
\hline ClO s age & Minimum & 22.0 & & 27.0 & \\
\hline & Maximum & 60.0 & & 62.0 & \\
\hline
\end{tabular}

Table 3: Outsourcing Level

\begin{tabular}{|c|l|r|r|r|r|}
\hline \multicolumn{2}{|c|}{} & \multicolumn{2}{|c|}{2001} & \multicolumn{2}{c|}{2006} \\
\cline { 2 - 6 } \multicolumn{2}{|c|}{} & \multicolumn{1}{c|}{ N } & \multicolumn{1}{c|}{$\%$} & \multicolumn{1}{c|}{ N } & \multicolumn{1}{c|}{$\%$} \\
\hline National & No & 51 & 14.3 & 54 & 16.4 \\
Outsourcing & Yes & 306 & 85.7 & 275 & 83.6 \\
\hline Global & No & - & - & 275 & 83.6 \\
Outsourcing & Yes & - & - & 54 & 16.4 \\
\hline
\end{tabular}


Table 4: Resource ownership

\begin{tabular}{ll|l|l|l|l|l|l|l|}
\hline The client firm is never the owner & 1 & 2 & 3 & 4 & 5 & 6 & 7 & The client firm is always the owner
\end{tabular}

\begin{tabular}{ll|l|l|l|l|l|l|l|}
\cline { 2 - 7 } Activities are never developed at the client's facilities & 1 & 2 & 3 & 4 & 5 & 6 & 7 & Activities are always developed at the client's facilities \\
\hline
\end{tabular}

\begin{tabular}{|l|ccccc|}
\cline { 2 - 5 } \multicolumn{1}{c|}{} & Mean & Median & Mode & Maximum & Minimum \\
\hline The client firm owns the hardware & 5.9 & 7 & 7 & 7 & 1 \\
The client firm owns the software & 5.4 & 7 & 7 & 7 & 1 \\
$\begin{array}{l}\text { The outsourced activities are developed at the } \\
\text { client's facilities }\end{array}$ & 4.6 & 5 & 7 & 7 & 1 \\
\hline
\end{tabular}

Figure 1: Outsourced Activities (longitudinal)

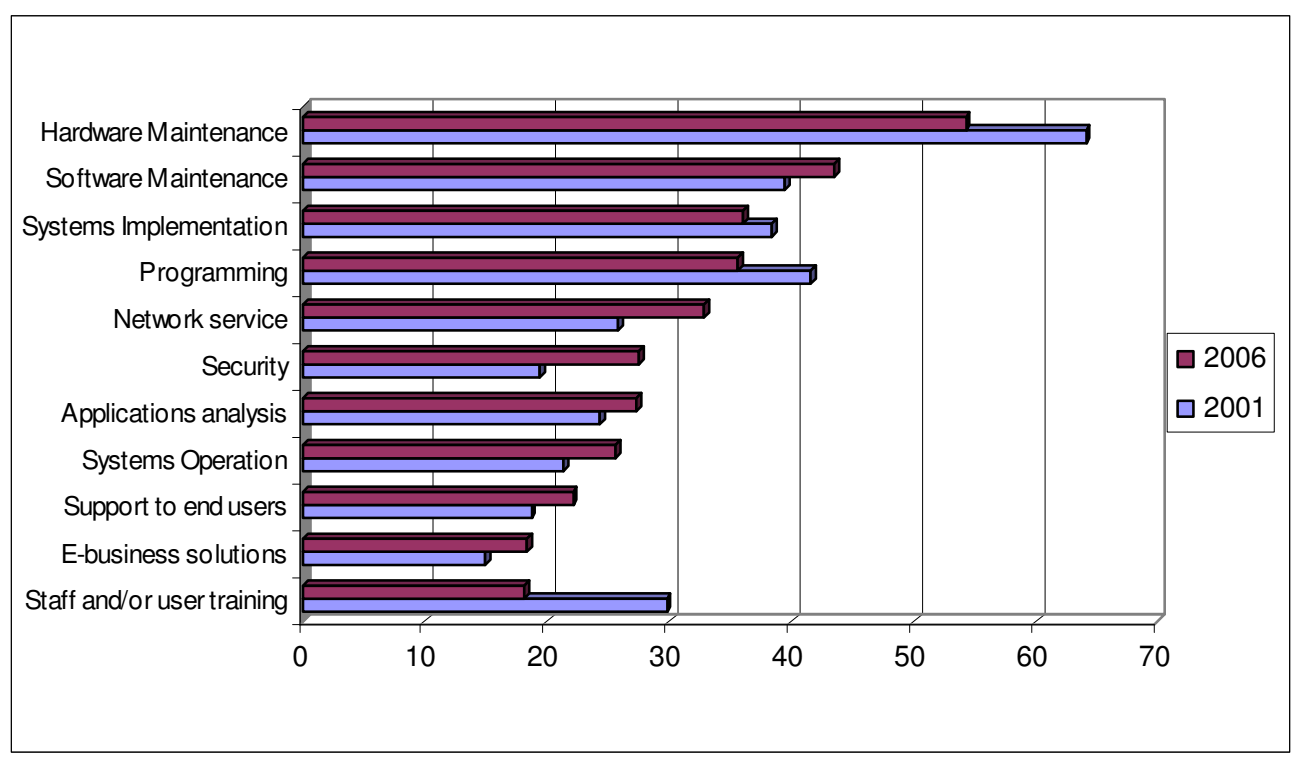

Figure 2: Addressees of Outsourced Activities

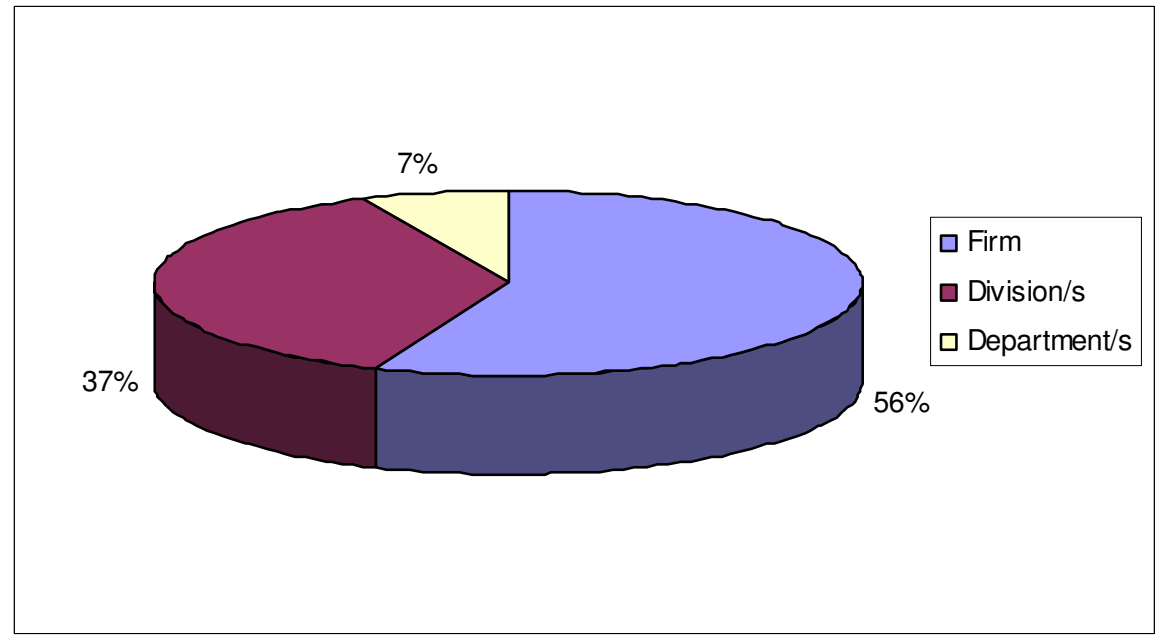


Figure 3: Number of Providers

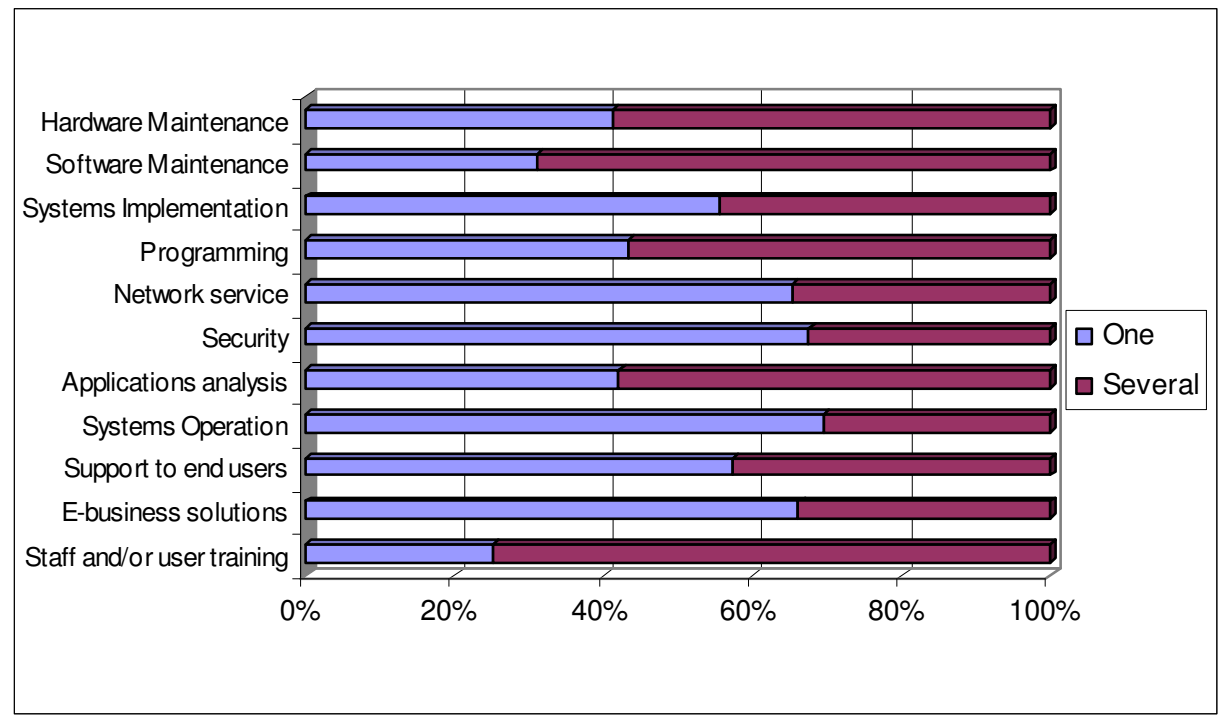

Figure 4: Several Providers (longitudinal)

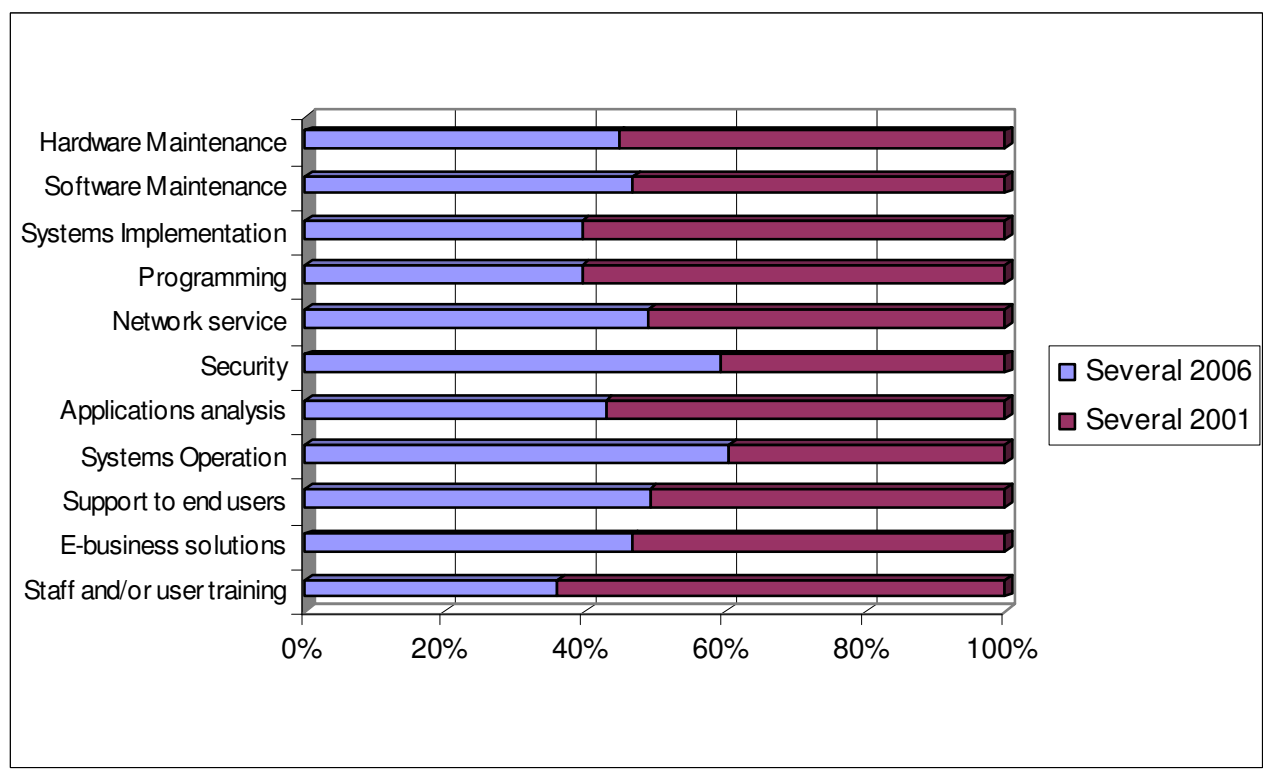


Figure 5: Price Structure

The least often used

structure

\begin{tabular}{|l|l|l|l|l|l|l|l}
\hline 1 & 2 & 3 & 4 & 5 & 6 & 7 & $\begin{array}{l}\text { The most often used } \\
\text { structure }\end{array}$ \\
\hline
\end{tabular}

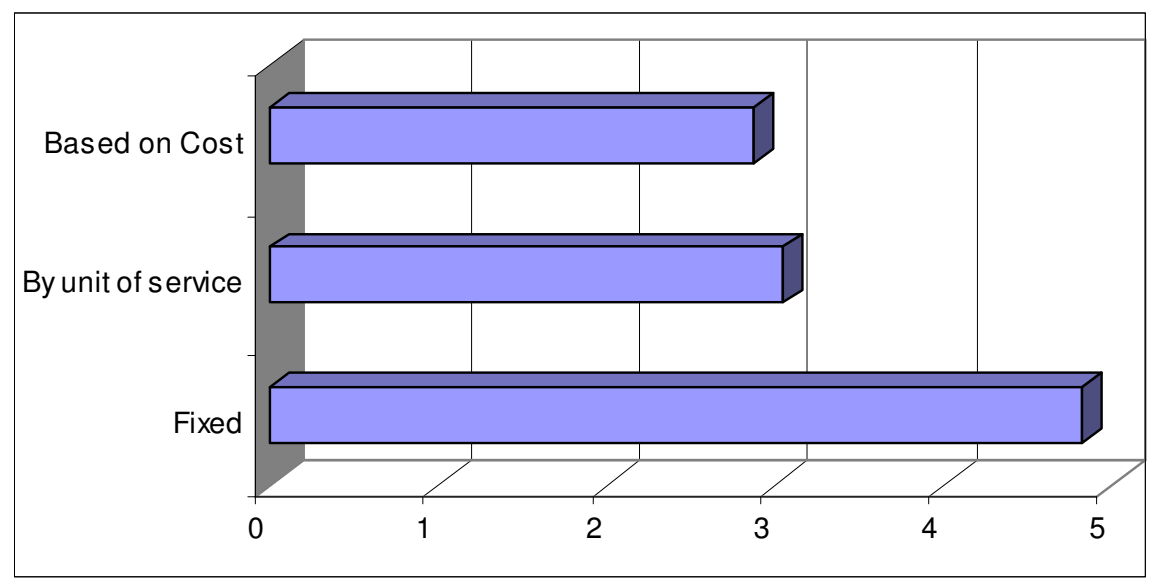

Figure 6: Outsourcing Contract Period (longitudinal) (\%)

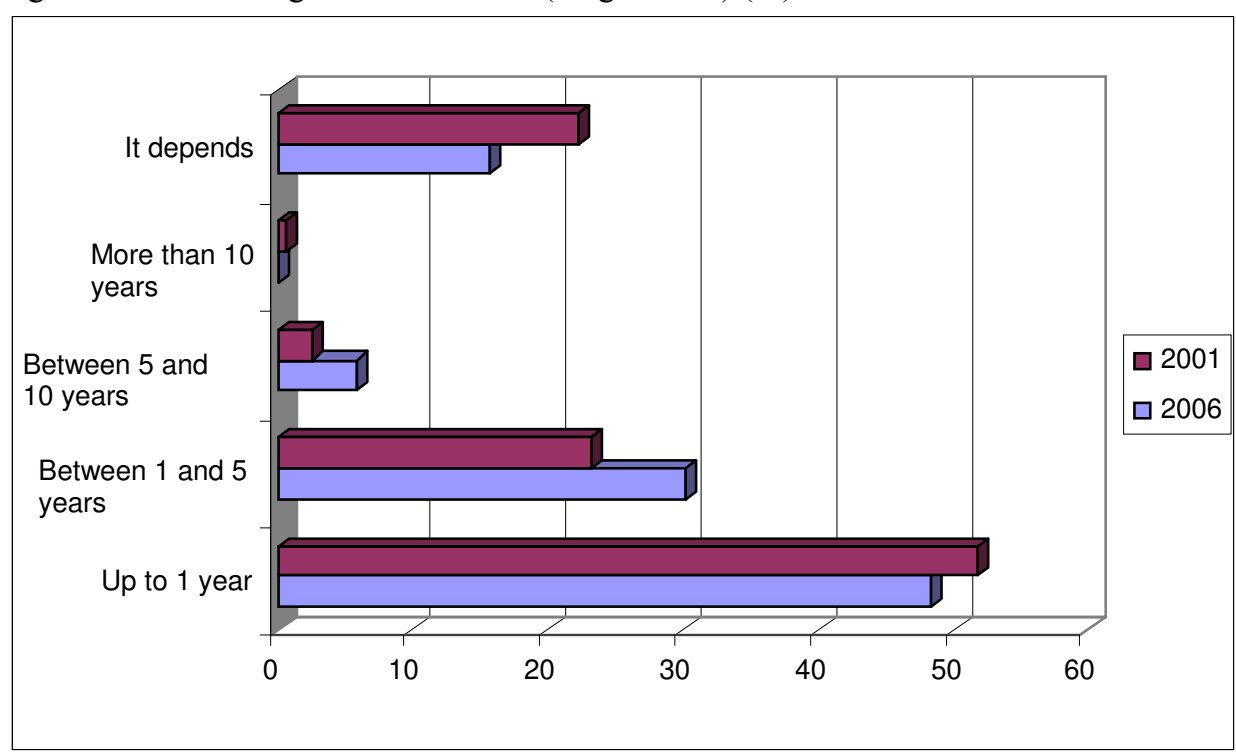


Figure 7: Commercial Relationship

The least frequent relationship \begin{tabular}{|l|l|l|l|l|l|l|}
\hline 1 & 2 & 3 & 4 & 5 & 6 & 7 \\
\hline
\end{tabular}

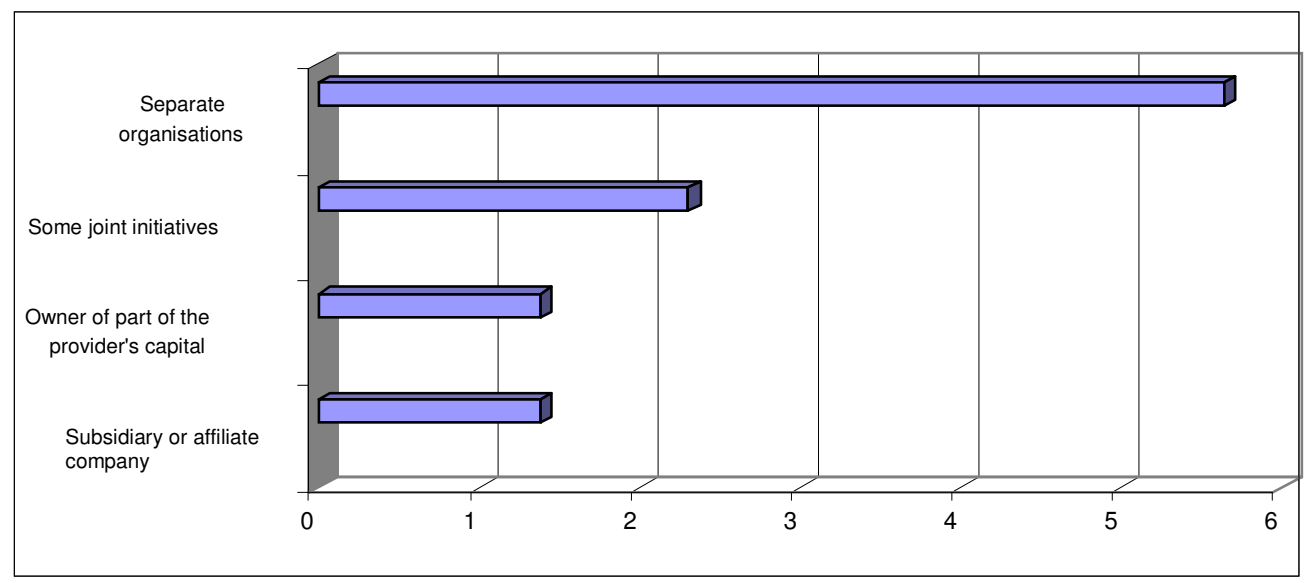

Figure 8: The Future of Outsourcing (\%)

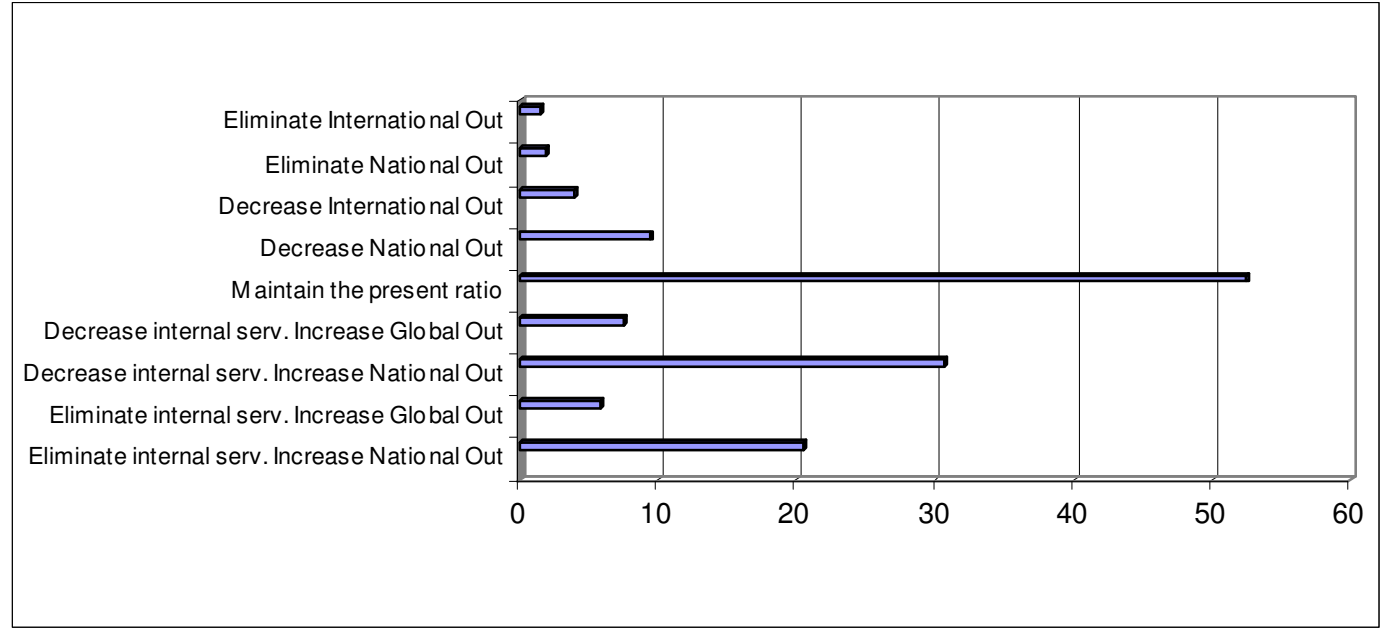

Figure 9: The Future of Outsourcing (longitudinal) (\%)

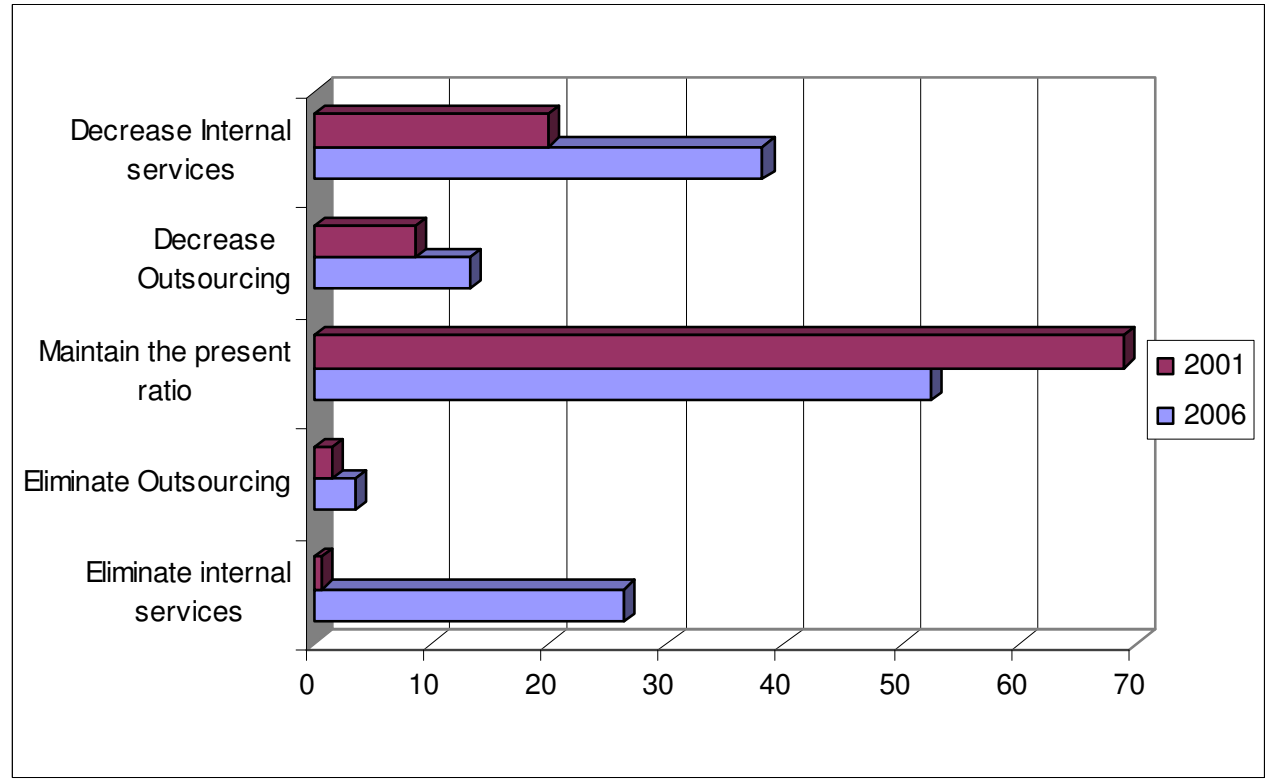

